\title{
Photovoltaic Energy-Assisted Electrocoagulation of a Synthetic Textile Effluent
}

\author{
Thelma Beatriz Pavón-Silva ${ }^{(D},{ }^{1}$ Hipólito Romero-Tehuitzil, ${ }^{2}$ Gonzálo Munguia del Río, ${ }^{2}$ \\ and Jorge Huacuz-Villamar ${ }^{2}$ \\ ${ }^{1}$ Unidad Académica Profesional-Acolman, Universidad Autónoma del Estado de México, Camino de Caleros No. 11, Ejidos de Santa \\ Catarina, Acolman, MEX, Mexico \\ ${ }^{2}$ Instituto Nacional de Electricidad y Energías Limpias, Av. Reforma 113, Col. Palmira, 62490 Cuernavaca, MOR, Mexico
}

Correspondence should be addressed to Thelma Beatriz Pavón-Silva; th.pavon@gmail.com

Received 13 July 2017; Revised 9 October 2017; Accepted 7 November 2017; Published 7 March 2018

Academic Editor: Carlos A. Martínez-Huitle

Copyright (c) 2018 Thelma Beatriz Pavón-Silva et al. This is an open access article distributed under the Creative Commons Attribution License, which permits unrestricted use, distribution, and reproduction in any medium, provided the original work is properly cited.

The feasibility of using photovoltaic modules to power a continuous $14 \mathrm{~L}$ electrochemical reactor applied to remove an azo dye with an efficiency of $70 \%$ is reported. The photovoltaic modules were directly connected, and the system efficiency was observed properly maintained when currents were applied in the range of 2.5 to $7.9 \mathrm{~A}$. This value depends on solar radiation. Likewise, it was found that the efficiency depends mainly on the current density and the flow rate prevailing in the reactor.

\section{Introduction}

The problem of industrial wastewater is a topic that deserves special attention, particularly for industries that use dyes and thus generate large volumes of polluted wastewater. Due to their high molecular weights, complex structures, and especially high solubility in water, dyes persist once discharged into a natural environment, for example, textile $[1,2]$, pharmaceutical [3], cosmetics and food industry [4], and industrial wastewater [5]. Specifically for the textile industry, the chemical structure of these compounds is complex, generally of the type azo [6-8]. This group consists of colored substances with a complex chemical structure (many functional groups) and a high molecular weight. Thus, their removal from industrial effluents is also a subject of major importance from the environmental point of view. The removal of dissolved organic matter by coagulation is widely reported in literature [9], where the primary mechanism consists of two methods [10]. The first is binding the metal species to anionic sites of the organic molecules, thereby neutralizing their charge and resulting in reduced solubility. The second is the absorption of organic substances on amorphous metal hydroxide precipitates.
Chemical coagulation/flocculation is the most widely used technique for textile wastewater treatment; they have some disadvantages, such as needing $\mathrm{pH}$ adjustment before and after treatment, producing large amounts of sludge, and adding undesirable inorganic chemicals like aluminum, iron, sulfate, and chloride to the environment [11].

The results for the optimization of the effect of the coagulation-flocculation showed the rate of dye removal increased from $11.25 \%$ to 13.20 for the methylene blue and from $27.5 \%$ to 29.25 for the indigo carmine when the concentration of coagulant and flocculant were varied from 40 to $120 \mathrm{mg} \cdot \mathrm{L}^{-1}$. These results confirm the poor applicability of this process for the elimination of such dyes. Assadia et al. [12] show that ferric chloride and alum at optimum concentration were capable of removing dye and COD by $79.63 \%$ and $84.83 \%$ and $53 \%$ and $55 \%$, respectively.

The electrocoagulation process is deemed an economical and environmental choice to minimize the drawbacks of conventional wastewater treatment technologies [13]; it provides a number of benefits, such as low cost, compatibility, and safety [14]. In addition, electrocoagulation has been proven to eliminate complex contaminants in wastewater that require a combination of physicochemical and biological 
methods [15-17]. Its combination with other processes, like ozonation [18], has also been demonstrated to be highly effective for complex matrix wastewater remediation. The application of electrocoagulation, however, has been restricted at some extent by the cost that implies electrical energy usage. Moreover, climate change motivates research and development of new forms of renewable energy $[19,20]$ such as photovoltaic (PV) power [8], whose advantages include its free use and abundant availability, is a renewable resource, decentralized, with long life span and low maintenance costs, and does not result in contamination.

In this research, a PV system was evaluated in a pilot electrochemical wastewater reactor using a synthetic wastewater model containing azo dye, in this case remazol yellow dye 3GL (RYD), which is mainly used in textile industry $[4,8,21]$. This was first accomplished with batch tests and then with continuous tests in a pilot reactor, both of which are based on previously reported studies [8].

\section{Experimental}

The experimental setup is shown in Figure 1 and consists of the following: (1) the sun as a renewable energy source; (2) photovoltaic modules to convert sunlight into electricity; (3) an acrylic cylindrical reactor with a $0.15 \mathrm{~m}$ diameter and one meter length (14 L of water was treated); (4) direct connection of the sun to the electrochemical reactor, two aluminum electrodes formed by 39 circular blades $(0.12 \mathrm{~m}$ diameter) with total surface area of $0.44 \mathrm{~m}^{2}$, separated from each other by one centimeter. (5) Registration data and continuous monitoring was performed by a data acquisition system: current, voltage, and solar radiation. (6) The $\mathrm{pH}$, conductivity, and temperature were measured with an electrical conductivity meter.

2.1. Reagents. The working solution was prepared by dissolving remazol yellow dye (RYD) 3GL (DyStar SA ${ }^{\mathrm{TM}}$ ) in potable water and was used as wastewater model containing azo dye (RYD) as pollutant. Table 1 summarizes its characteristics.

The conductivity was set at $366-380 \mu \mathrm{S} / \mathrm{cm}$, and this in concordance with Can et al. [22], who stated this parameter to be lower than $500 \mu \mathrm{S} / \mathrm{cm}$. They investigated the conductivity between 250 and $4000 \mu \mathrm{S} / \mathrm{cm}$ using $\mathrm{NaCl}$ as the support electrolyte and noticed that above 500, the remazol red dye removal efficiency decreases. In our case, due to the size of the reactor ( $14 \mathrm{~L}$ pilot reactor), it was decided to work with potable water that already has a conductivity of $302-315 \mu \mathrm{S} / \mathrm{cm}$, so an electrolyte support was not added. Thus, as reported by Can et al., the decline in the fading efficiency with increasing conductivity can be attributed to a change in ionic strength due to the change in conductivity of the aqueous medium. Ionic strength affects the kinetics and equilibrium of reactions between charged species during electrocoagulation.

2.2. Determination of Remazol Yellow Dye (RYD). RYD concentration was determined by UV-Vis spectrophotometry in a Perkin Elmer Lambda 2 spectrophotometer. The concentration of the molecule was determined by its

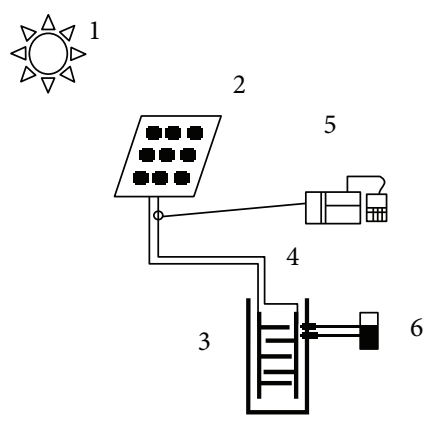

FIgURE 1: Scheme of the experimental system: 1, solar energy; 2, photovoltaic module; 3, electrochemical reactor; 4, direct connection of the power supply; 5, parameter control: current, voltage, and solar radiation; $6, \mathrm{pH}$, conductivity, and temperature control.

TABLE 1: Characterization of the remazol yellow dye.

\begin{tabular}{lc}
\hline Parameter & Valor \\
\hline Color index & Remazol yellow \\
Chromophore & Azo \\
Molar mass $\left(\mathrm{g} \cdot \mathrm{mol}^{-1}\right)$ & 362.27 \\
Percentage of pure dye & $68 \%$ \\
pKa & 3.77 \\
Water solubility at $293 \mathrm{~K}\left(\mathrm{~g} \cdot \mathrm{L}^{-1}\right)$ & 80 \\
Acute oral toxicity LD50 $\left(\mathrm{mg} \cdot \mathrm{kg}^{-1}\right)$ & $>2000$ \\
pH value $\left(\right.$ at $10 \mathrm{~g} \cdot \mathrm{L}^{-1}$ water $)$ & 6.1 \\
Conductivity $\left(\mathrm{mS} \cdot \mathrm{cm}^{-1}\right)$ & $302-308$ \\
\hline
\end{tabular}

absorption at $269.2 \mathrm{~nm}$. The calibration curve was carried out between 0 and $100 \mathrm{mg} \cdot \mathrm{L}^{-1}$ of RYD obtaining the following model: $\mathrm{A}=0.0301(\mathrm{C})-0.0003$, where $\mathrm{A}=$ absorption and $\mathrm{C}=$ concentration of RYD. The determination coefficient was $r^{2}=0.9994$. Color determination was conducted in a Hach DR/3000 spectrophotometer.

2.3. Removal Efficiency of RYD. The removal efficiency of RYD was calculated as

$$
E(\%)=\frac{C_{1}-C_{\mathrm{f}}}{C_{1}} * 100,
$$

where $C_{1}$ is the initial dye concentration and $C_{\mathrm{f}}$ is the final dye concentration, both in $\mathrm{mg} \cdot \mathrm{L}^{-1}$; this expression was also used in case of color determination where $C_{1}$ and $C_{\mathrm{f}}$ are color intensities in Pt/Co units [23].

2.4. Chemical Oxygen Demand. Chemical oxygen demand was determined according to standard techniques, APHA/ AWWA/WPCE [24].

The removal efficiency or percentage of COD removal (\%RE) was then calculated as follows $[25,26]$ :

$$
E(\%)=\frac{\mathrm{COD}_{0}-\mathrm{COD}_{\mathrm{f}}}{\mathrm{COD}_{0}} * 100,
$$


where $\mathrm{COD}_{0}$ is the initial chemical oxygen demand and $\mathrm{COD}_{\mathrm{f}}$ is the final chemical oxygen demand, both in $\mathrm{mg} \cdot \mathrm{L}^{-1}$.

2.5. Sampling. The determination of RYD and the removal efficiency of RYD and COD correspond to the samples taken in the upper part of the reactor and later filtered with Whatman paper number 1 . The samples were withdrawn from the reactor every $5 \mathrm{~min}$ for analysis.

2.6. Applied Current Intensity. The experimental tests were divided into two stages. First, a series of discontinuous tests with current intensities of $4,6,8$, and 10 A controlled by a power supply during 60 minutes (system DC power supply, Agilent Technologies N5700 series) were carried out and then with current intensities of $2,3,4$, and 5 . The second phase was carried out in a continuous flow, during approximately 6 hours; the current intensity was applied according to the results obtained in the discontinuous tests.

The objective in this stage was to evaluate the intensity of the current that is variable, depending on the following flow rates: $300,500,700$, and $1000 \mathrm{~mL} \cdot \mathrm{min}^{-1}$, in order to check the contact time between the dye and the electrode to evaluate the percentage of removal of RYD through photovoltaic live connection.

The electrodes were treated by rinsing them with a $1 \mathrm{M}$ $\mathrm{HCl}$ solution and distilled water at the end of each test.

2.7. Photovoltaic Array. The photovoltaic array consisted of two Siemens Solar photovoltaic (PV) modules Solar $75 \mathrm{Wp}$, SP-75. The solar module characteristics were verified using the I-V Checker MP140 Portable PV Device Evaluation Instrument, for which the PV module was first determined, and afterwards, with two PV modules connected in parallel [8], the short circuit current increases with the number of modules connected in parallel. The experiments were carried out at the Institute of Electrical Research (latitude $18^{\circ} 52^{\prime}$ $40.99^{\prime \prime} \mathrm{N}$, longitude $99^{\circ} 13^{\prime} 6.89^{\prime \prime} \mathrm{O}$, inclination $19^{\circ}$, and south oriented).

Table 2 shows the PV module characterization for one and two PV modules connected in parallel. If one solar module is considered, the acquired current is $3.8 \mathrm{~A}$ and is sufficient to obtain similar removal results as accomplished by the power source. In the case of a cloudy day where there is low solar radiation, the application of two modules would be required. Parallel-connected solar PV modules would offer a required minimum current intensity in the reaction performance with reasonable efficiency. The calibration of both modules set in parallel array produces a current intensity of $7.9 \mathrm{~A}$.

\section{Results and Discussion}

3.1. Batch Tests with Artificial Power Source. Table 3 shows that COD removal is time dependent while applying different current intensities. At lower current intensity, the removal efficiency of COD is higher; this variation can be attributed to an interference during COD determination caused by the presence of aluminum ions when applying more current. The electrochemical reaction will produce a higher number
TABLe 2: Characterization of solar PV modules.

\begin{tabular}{lcc}
\hline Parameter & 1 PV module & 2 PV module \\
\hline Solar irradiance $\left(\mathrm{W} / \mathrm{m}^{2}\right)$ & 1007.3 & 1046.5 \\
Ambient temperature $\left({ }^{\circ} \mathrm{C}\right)$ & 25 & 25 \\
Cell temperature $\left({ }^{\circ} \mathrm{C}\right)$ & 58.4 & 57 \\
Short current $(\mathrm{A})$ & 4.4 & 9.0 \\
Open voltage $(\mathrm{V})$ & 18.5 & 18.8 \\
Max power $(\mathrm{W})$ & 51.5 & 107.3 \\
Max power current $(\mathrm{A})$ & 3.8 & 7.9 \\
Max power voltage $(\mathrm{V})$ & 13.5 & 13.6 \\
Fill factor $(\mathrm{FF})$ & 0.63 & 0.63 \\
\hline
\end{tabular}

TABle 3: Removal efficiency of COD $\mathrm{mg} \cdot \mathrm{L}^{-1}$ by different current intensities.

\begin{tabular}{lcccc}
\hline & \multicolumn{4}{c}{ Current (A) } \\
Time (min) & 4.0 & 6.0 & 8.0 & 10.0 \\
\hline 15 & 52.9 & 48.0 & 42.2 & 37.8 \\
30 & 70.6 & 48.0 & 39.0 & 76.5 \\
45 & 77.5 & 41.2 & 61.8 & 64.3 \\
60 & 43.1 & 40.2 & 49.0 & 57.7 \\
\hline
\end{tabular}

of aluminum ions, and this explains why the removal efficiency decreases during the treatment time.

It is known that the current intensity applied to the system determines the amount of released ions and therefore the amount of the resulting coagulant. Thus, the higher the amount of dissolved $\mathrm{Al}^{3+}$ ions in a solution, the greater the rate of $\mathrm{Al}(\mathrm{OH})_{3}$ formation, and consequently a higher COD removal efficiency is expected to be achieved. In addition, the increase of current density promotes the generation of $\mathrm{H}_{2}$ bubbles and decreases its size, which should lead to a higher removal of pollutants by flotation. However, higher current values may promote a higher turbulence in the system, and consequently, the particles responsible for coagulation do not have enough time to agglomerate themselves and remove the pollutants [27] as stated by Fajardo et al. (2015).

The ions generated in the electrode are $\mathrm{Al}(\mathrm{aq})^{3+}$ and $\mathrm{OH}^{-}$; the combination of these ions is expected to form various monomeric species such as $\mathrm{Al}(\mathrm{OH})^{2+}, \mathrm{Al}(\mathrm{OH})_{2}{ }^{+}$, $\mathrm{Al}_{2}(\mathrm{OH})_{2}{ }^{4+}$, and $\mathrm{Al}(\mathrm{OH})_{4}{ }^{-}$and polymeric species such as $\mathrm{Al}_{6}(\mathrm{OH})_{15}{ }^{3+}, \quad \mathrm{Al}_{7}(\mathrm{OH})_{17}{ }^{4+}, \quad \mathrm{Al}_{8}(\mathrm{OH})_{20}{ }^{4+}, \quad \mathrm{Al}_{13}(\mathrm{OH})_{34}{ }^{5+}$, and $\mathrm{Al}_{13}(\mathrm{OH})_{37}{ }^{2+}[23,24]$. By relating these species with the report about super-faradaic efficiencies [28, 29], they are more significant at low current densities, that is, $1.75 \mathrm{~mA} \cdot \mathrm{cm}^{-2}$. In the case of aluminum, experimental results are significantly over the expected values for a $100 \%$-efficiency process according to Faraday's law, (3). This super-faradaic efficiency is explained in terms of a chemical dissolution process, which corresponds to the oxidation of the aluminum sheets with the simultaneous reduction of water to form hydrogen. It has also been mentioned that the amount of generated aluminum seems to depend on the $\mathrm{pH}$, and this has been explained in terms of chemical 
dissolution of the aluminum electrode. In this case, the $\mathrm{pH}$ was initially between 5.6 and 6.3. However, it was observed that as current increases, $\mathrm{pH}$ rapidly decreases. For example, at $I=4,6,8$, and $10 \mathrm{~A}$, the $\mathrm{pH}$ was $4.8,2.3,2.2$, and 1 , respectively. Gu et al. suggest that (4) and (5) for the oxidation of water will decrease solution $\mathrm{pH}$ [30] and this was observed in this work, so, the super-faradaic efficiencies are greater for aluminum than those for iron [29].

The $\mathrm{pKa}$ of the remazol yellow dye is 3.77. Therefore, above this $\mathrm{pH}$, the species of ionic form will be found, and its chromophore groups will be negatively charged. When the removal efficiency decreases, it is suggested that the precipitated hydroxide metal may have tended to dissolve in liquid thus adversely affecting the performance of the process. This fact may take place as the medium turns extremely acidic or alkaline as previously reported [31-33]. The cationic metal species are responsible for the destabilization of the particles (charge neutralization), leading to the formation of flocculating particles, which will have the power to sediment contaminants [33]. In situ generation of coagulants has the advantage of reducing the amount of chemical reagents introduced into the system; however, this may lead to a change in $\mathrm{pH}$. In this context, the $\mathrm{pH}$ of the batch tests has been reported acidic and in the continuous tests, the $\mathrm{pH}$ fluctuated between 7.8 and 8.9 , so the predominant reaction will be represented by (3) [29].

$$
2 \mathrm{Al}+6 \mathrm{H}_{2} \mathrm{O} \rightarrow 2 \mathrm{Al}+3 \mathrm{H}_{2}+6 \mathrm{OH}^{-}
$$

According to the diagram of Pourbaix [34], at $\mathrm{pH}$ less than $4, \mathrm{Al}^{3+}$ ions are expected, and between 4 and 8 , there may be passivation by $\mathrm{Al}_{2} \mathrm{O}_{3}$. For this study, however, it is observed that the $\mathrm{pH}$ and therefore the predominant reactions depend on the flow regime, that is, in batch tests, an acidic $\mathrm{pH}$ is observed and (4) and (5) predominate, and in tests under continuous flow, the $\mathrm{pH}$ is between neutral and slightly alkaline, and without considering the effect of passivation, (3) is the predominant one as already mentioned.

$$
\begin{aligned}
& 2 \mathrm{H}_{2} \mathrm{O} \rightarrow \mathrm{O}_{2}+4 \mathrm{H}^{+}+4 \mathrm{e}^{-} \\
& 2 \mathrm{OH}^{-} \rightarrow \mathrm{O}_{2}+2 \mathrm{H}^{+}+4 \mathrm{e}^{-}
\end{aligned}
$$

Another phenomenon is the production of aluminum, so in Table 3, there is an increase of COD, although the color tends to decrease. As it is known, this production is a function of the applied current. Thus, considering the electrode area $\left(0.44 \mathrm{~m}^{2}\right)$ and applying Faraday's law (6), the following values of $\mathrm{Al}^{3+}$ are calculated, $0.32,0.48,0.64$, and $0.81 \mathrm{~g}$, for currents of $4,6,8$, and $10 \mathrm{~A}$, accordingly. It is possible to have an excess of ions and for this reason, the COD value does not fall [5].

$$
n=\frac{M I t}{z F}
$$

where $n$ is the metal $(g), M$ molecular mass of electrode, $I$ current intensity, $t$ operating time, $z$ number of electron transferred, and F Faraday's constant $(96,500 \mathrm{C} / \mathrm{mol})$.

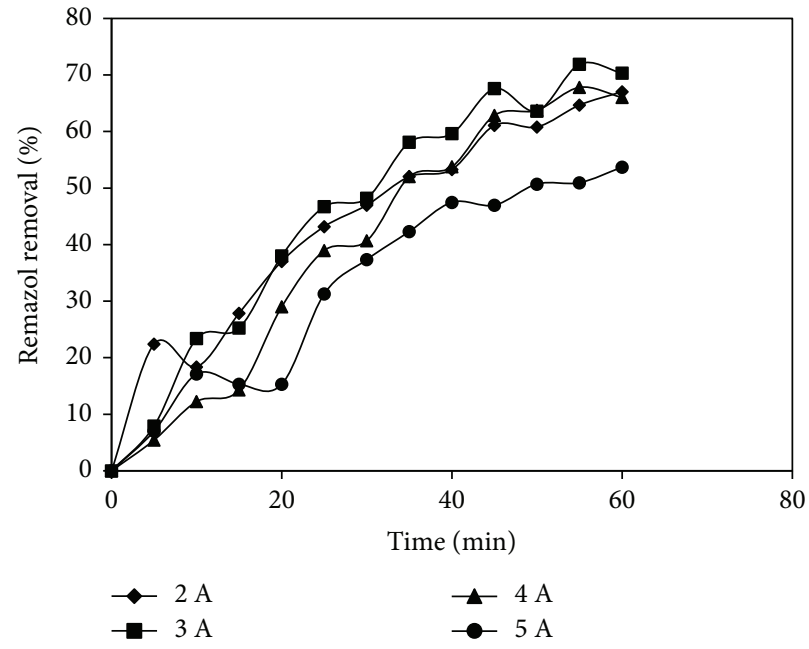

FIgURe 2: Removal of RYD at different current intensities: $2 \mathrm{~A}, 3 \mathrm{~A}$, $4 \mathrm{~A}$, and $5 \mathrm{~A}$.

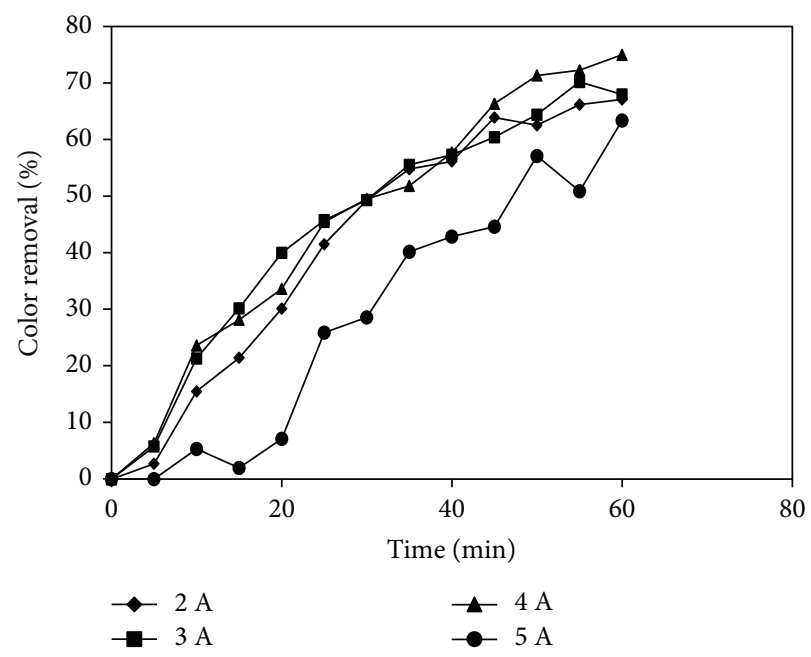

FIgURE 3: Color removal at different current intensities: $2 \mathrm{~A}, 3 \mathrm{~A}$, $4 \mathrm{~A}$, and $5 \mathrm{~A}$.

In the case of aluminum, experimental results are significantly over the expected values for a 100\%-efficiency process according to Faraday's law. This super-faradaic efficiency is explained in terms of a chemical dissolution process, which corresponds to the oxidation of the aluminum sheets with the simultaneous reduction of water to form hydrogen, according to (3) [29].

3.2. Optimization of the Applied Current with the Power Source. According to the results of Table 3, the applied current must be less than $6 \mathrm{~A}$; so for these tests, currents to be evaluated were selected from 2, 3, 4, and 5 A. Figure 2 shows the dye removal percentage at these current intensities where a significant difference does not appear when applying 2,3 , or $4 \mathrm{~A}$, as compared to $5 \mathrm{~A}$ ANOVA and Duncan test $(p>0.5)$ [35]. 
Figure 3 shows the dye color removal percentage at the same currents; these current intensities have the same behavior as in the removal of dye concentration.

In Figures 2 and 3, a similar behavior is observed regarding the elimination of the dye elaborated with the UV-Vis spectrophotometer and the elimination of the color; they have very similar efficiencies. When performing the ANOVA, it is similar to the dye efficiency tests that with a current of 2,3 , and $4 \mathrm{~A}$, there is no significant difference in the results and with respect to $5 \mathrm{~A}$, if there is a significant difference $(p>0.5)$.

3.3. Batch Examinations with PV Modules. Table 1 shows that one PV module is enough to generate a current of $4 \mathrm{~A}$ under good solar radiation conditions, and two solar PV modules in parallel array are capable to generate 7.9 A. This means that in cloudy weather conditions, the current generated by two solar PV modules must be in the necessary range to carry out the RYD removal tests. Then, under this assumption, Figure 4 shows the comparison for RYD removal with the power source in $3 \mathrm{~A}$ and $4 \mathrm{~A}$ and one solar PV module. During this testing period, the solar PV module had an average solar radiation of $747 \mathrm{~W} / \mathrm{m}^{2}$ and a current of $3.1 \mathrm{~A}$, with an average voltage of $2.37 \mathrm{~V}$; the $\mathrm{pH}$ dropped slightly from 8 to 6.5 units, while the temperature in the electrocoagulation reactor increased from 18.5 to $20^{\circ} \mathrm{C}$. As shown in Figure 4, there are no differences in the RYD results from the power source and solar PV modules. Observing that the removal efficiency is lower for $5 \mathrm{~A}$, it is established that the appropriate conditions for the work of the system with the solar panel will be sufficient if it reaches between 2 and $4 \mathrm{~A}$ of current. This will depend on the solar irradiation of the moment; since the solar modules are connected directly, the solar irradiation impacts directly to the electrochemical reactor, generating greater or less quantity of ions to participate in the electrocoagulation. If there is a sunny and cloudless day, adequate solar radiation is guaranteed, which is why 1 or 2 photovoltaic panels are used. This is a complement of Figures 2 and 3 where we observe the similarity in the color and concentration removals of the RYD, and if we contrast this with Figure 4 which is already an experimental process, it is possible to use one or two photovoltaic modules, considering the use of only one module for the conditions treated in these experiments.

3.4. Examination in Continuous Flow Rate. Figure 5 shows how the removal of the dye and color removal (65-70\%) are kept constant in the test from 1.5 hours and onwards with a flow rate of $300 \mathrm{~mL} \cdot \mathrm{min}^{-1}$ and the PV current supplied by either one or two PV modules. Contrasting this graph with Figure 6 , the radiation in either case, with one and two photovoltaic modules, can be observed. It is worth noting that there is a significant variation with the use of two photovoltaic modules. This can be ascribed to the day being cloudy and although it worked with the two modules reaching currents from 3.08 to 7.93 and 0.78 to 3.92 with one module, a variation is reflected although in an appropriate range for the minimum current needed for the electrochemical process. Thus, the use of two modules allows to attain currents

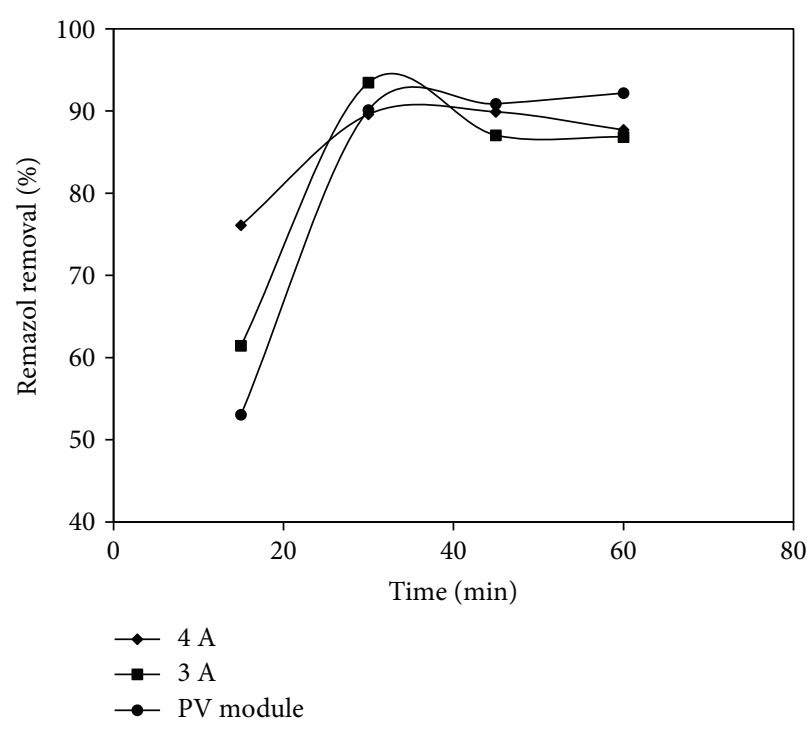

FIgURE 4: Comparison between current intensity controlled with the power source and one module solar: $4 \mathrm{~A}, 3 \mathrm{~A}$, and PV module.

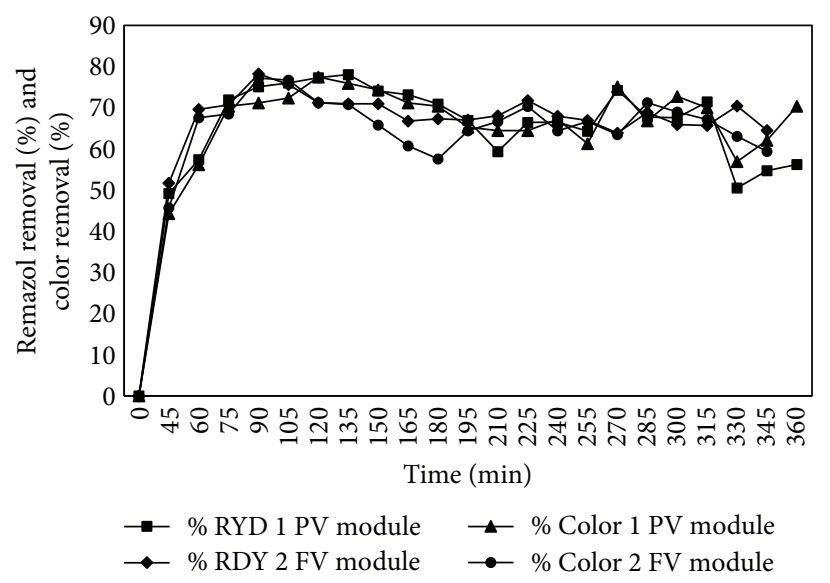

FIgURE 5: Remazol removal and color removal under continuous flow with the application of photovoltaic modules: liquid flow rate: $300 \mathrm{~mL} \cdot \mathrm{min}^{-1}$; initial concentration of RYD: $100 \mathrm{mg} \cdot \mathrm{L}^{-1}$. \% RYD one PV module, \% RYD one PV module, color one PV module, and color two PV module.

higher than $3 \mathrm{~A}$ at all times. According to Figure 4, this value is sufficient for the process to occur. When only one module is used, the current will depend on the daytime and the variation may be rather rapid. For example, at 9:00 in the morning, a 0.78 A current was obtained, while 50 minutes later, the measured current was already $2 \mathrm{~A}$. This trend usually prevails until 15:h. On the other hand, when two solar modules are used, the minimum attained current is $3.08 \mathrm{~A}$, and between 10:00 and 15:30, the current is always higher than $3 \mathrm{~A}$. Therefore, it can be concluded that two modules will always provide the adequate current regardless of the solar radiation intensity during daytime.

The tests by different flow rates are shown in Figure 7. As it can be observed, the differences of the dye removal efficiencies are not significant for flow rates of 500, 700, 


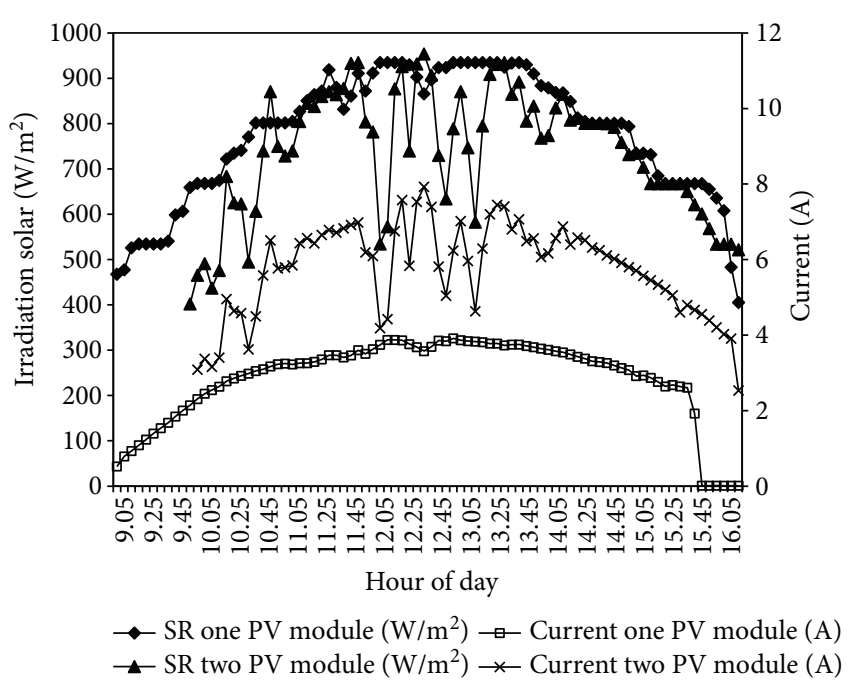

FIGURE 6: Solar irradiation profiles as function of time: SR one PV module, SR two PV module, current one PV module, and current two PV module.

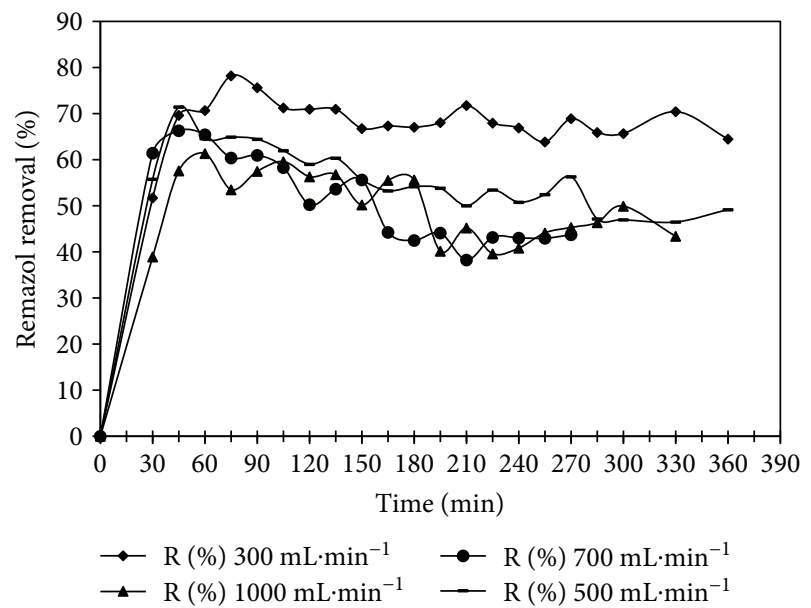

Figure 7: Effect of removal percentage rate on RYD initial concentration remazol $100 \mathrm{mg} \cdot \mathrm{L}^{-1}$ : \% RYD $300 \mathrm{~mL} \cdot \mathrm{min}^{-1}$, \% RYD $500 \mathrm{~mL} \cdot \mathrm{min}^{-1}$, \% RYD $700 \mathrm{~mL} \cdot \mathrm{min}^{-1}$, and \% RYD $1000 \mathrm{~mL} \cdot \mathrm{min}^{-1}$.

and $1000 \mathrm{~mL} \cdot \mathrm{min}^{-1}$; however, at $300 \mathrm{~mL} \cdot \mathrm{min}^{-1}$ flow rate, the difference is around $20 \%[36,37]$. This effect was expected since lower flow rates also imply higher residence time. It can be concluded that RYD removal efficiency is favored when the retention time, electric current, and flow rate are low $[38,39]$.

Table 4 shows the average, maximum, and minimum values of solar radiation, current intensity, and voltage for the accomplished tests by different flow rates comparing each one of $300 \mathrm{~mL} \cdot \mathrm{min}^{-1}$ with the remaining other. It is possible to observe that the current intensity is lower at 300 and $500 \mathrm{~mL} \cdot \mathrm{min}^{-1}$; however, the removal efficiency is better in the low flow rate. This proves that current above $5 \mathrm{~A}$ does not increase the removal efficiency.

As shown, there is variation in the current intensity for each test, because it is not possible to compare them,
TABLE 4: Evaluated parameters during different RYD flow rate.

\begin{tabular}{lccc}
\hline $\begin{array}{l}\text { Flow rate } \\
\left(\mathrm{mL} \cdot \mathrm{min}^{-1}\right)\end{array}$ & $\begin{array}{c}\text { Solar radiation } \\
\left(\mathrm{W} / \mathrm{m}^{2}\right)\end{array}$ & $\begin{array}{c}\text { Voltage } \\
(\mathrm{V})\end{array}$ & $\begin{array}{c}\text { Current } \\
\text { intensity }(\mathrm{A})\end{array}$ \\
\hline 300 & $741.4(437.5-954)$ & $3.9(1.92-4.9)$ & $5.7(2.53-7.93)$ \\
500 & $624.4(461-777)$ & $4.3(3.9-4.9)$ & $5.5(3.94-6.97)$ \\
700 & $861.7(688-957)$ & $6.6(4.5-7.56)$ & $7.4(3.52-8.41)$ \\
1000 & $857.4(602-977)$ & $6.2(3.34-8.23)$ & $7.4(3.45-8.45)$ \\
\hline
\end{tabular}

Average value (minimum-maximum).

however, since they are connected live; it depends on the solar radiation received on the day of the test; it can only be confirmed that it will be necessary to modify the water flow rate according to the received radiation so that it is proportional to what is reported in the literature as suitable to produce the amount of aluminum to react with the dye; nevertheless, it should not be forgotten that the phenomenon of super-faradaic production of the ion that helps the dye removal is also present. Under continuous flow, there is a synergy during treatment since after 1 hour of treatment, a stationary state is reached and a dye removal efficiency of $70 \%$ is attained. Worth noticing is that this value is kept constant until the treatment is complete (Figure 4). It is considered that it is necessary to establish a chain of batteries that are charged with photovoltaic energy to be able to carry out the elimination of pollutants continuously throughout the day, without being contingent to the solar radiation. That is, to store the energy and use it at the moment that it is required.

3.5. Energy Consumption. Figure 8 shows the energy consumption to remove $1 \mathrm{~g}$ of RYD by means of direct current and photovoltaic current at a flow rate of $300 \mathrm{~mL} \cdot \mathrm{min}^{-1}$. It can be seen that under controlled current supply with a DC power system, the energy consumption to remove RYD was constant and linear, $5.38 \mathrm{Wh} \cdot \mathrm{g}^{-1}$.

For RYD removal by means of PV current, this was dependent on solar radiation, reaching a maximum value of solar radiation around 1:00 p.m. and descended to the lowest value by the sunset.

Valero et al. $[39,40]$ demonstrated that the use of photovoltaic energy (i) reduces the cost of investment by avoiding the use of batteries, solar inverters, and power supplies and (ii) reduces the cost of maintenance, since there is no waste of batteries to properly dispose.

However, the disadvantage of this process is that in Mexico, it could only be applied from 9:30 am to 4:00 p.m., since it is the time in which there is adequate solar radiation in a sunny day. Sunny days are not constant through the year though. In order to overcome this, the use of hybrid energies combining solar photovoltaic with wind could be considered. This approach, however, should be evaluated taking into account that the increase of air is in the evening, so the working hours of an electrochemical reactor can be increased [41], considering the proposal of [39].

According to Figure 8, energy consumption to remove RYD color was dependent on the generated current by one or two PV modules. However, at the highest energy 


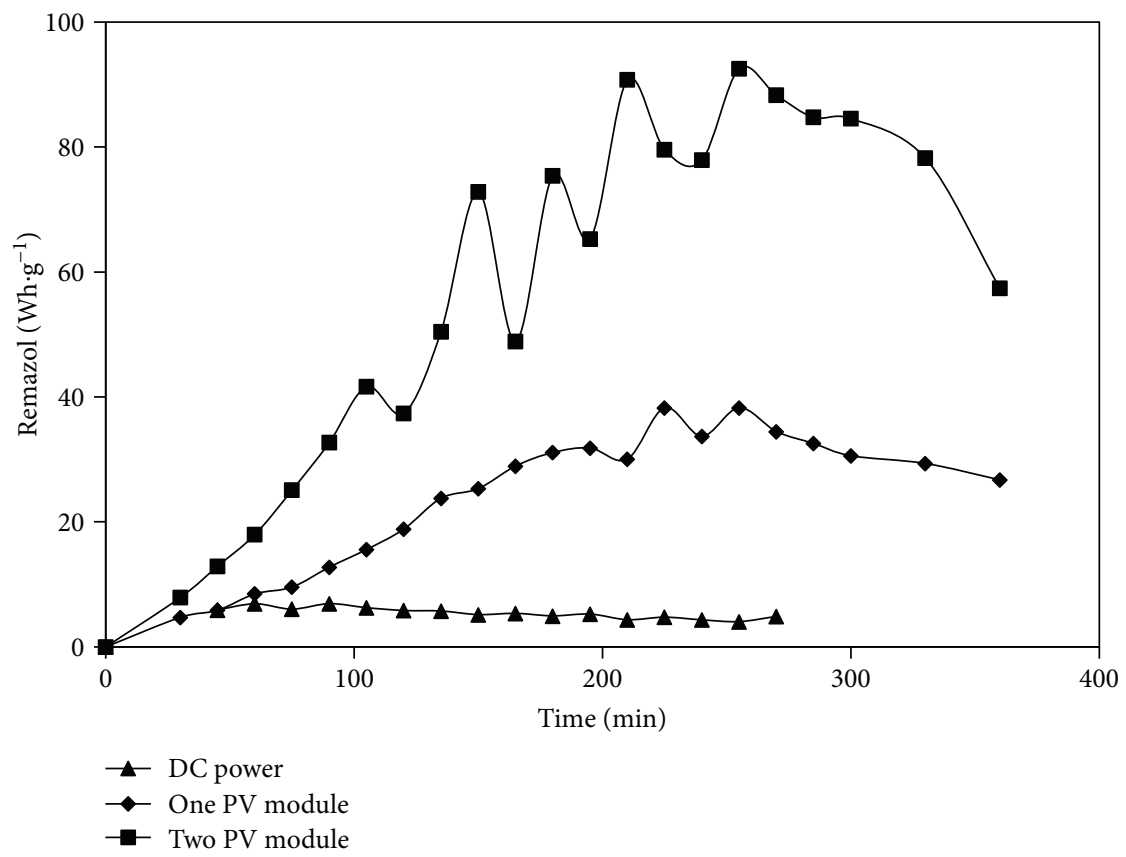

FIgURE 8: Comparison between CD and PV module.

consumption, RYD color removal shows a decay behavior due probably to a passivation phenomenon of the aluminum electrodes (see Section 3.1) and the consequent rising of electrical resistance thus causing the energy consumption increase.

Results reported at industrial scale show a parallel and series arrangement of the photovoltaic modules in order to obtain the electric current for the wastewater pollutant removal. However, the conditions of the photovoltaic arrangement will depend on the climatic conditions [40]. The setup for the pilot reactor of this work was twomodule photovoltaic in parallel for a cloudy day and onemodule photovoltaic for a sunny day.

Finally, regarding the PV energy costs, it will be possible to get a PV system at a low cost for the wastewater treatment. "Production costs for industry-leading Chinese crystallinesilicon (c-Si) PV module manufacturers - such as Jinko Solar, Renesola, Trina Solar and Yingli Green Energy will fall from 50 cents per watt in the fourth quarter of 2012 to 36 cents per watt by the end of 2017," according to a new report from GTM Research. The report, $P V$ Technology and Cost Outlook, 2013-2017 [42], predicts that the majority of these cost declines will derive from technology innovations such as diamond wire sawing for PV wafers, advanced metallization solutions, and increased automation in place of manual labor.

\section{Conclusions}

It is possible to use the photovoltaic modules to conduct wastewater treatment by electrocoagulation. In this work, the highest attained removal efficiency of RYD and color were $70 \%$ for both under continuous flow. The achieved current from one PV module was enough to generate electrocoagulation and remove RYD and color in a sunny day or two PV modules in parallel on a cloudy day. In order to obtain the electrocoagulation reaction, the current intensity should be between 3 and $4 \mathrm{~A}$. The recommended operation flow rate in the system is $300 \mathrm{~mL} \cdot \mathrm{min}^{-1}$; if the flow rate is increased, the removal efficiency decreases.

It is important to take into account the costs and the innovation in photovoltaics, since its implementation for scaling will depend on these, as well as on being able to install a complete system for storing solar energy and control the power to the system, always looking for the better pollutant removal efficiencies.

\section{Conflicts of Interest}

The authors declare that they have no conflicts of interest.

\section{References}

[1] C. Chienhung, N. Ervin, J. Yaju, and H. Chihpin, "Electrochemical decolorization of dye wastewater by surfaceactivated boron-doped nanocrystalline diamond electrode," Journal of Environmental Sciences, vol. 45, pp. 100-107, 2016.

[2] C. Davide, C. Giacomo, and M. Panizza, "Electrochemical oxidation of a synthetic dye using a BDD anode with a solid polymer electrolyte," Electrochemistry Communications, vol. 75, pp. 21-24, 2017.

[3] J. Rajeev, N. Sharma, and K. Radhapyari, "Electrochemical treatment of pharmaceutical azo dye amaranth from waste water," Journal of Applied Electrochemistry, vol. 39, pp. 577582, 2009.

[4] V. David, G.-G. Vicente, E. Eduardo, A. Antonio, and M. Vicente, "Electrochemical treatment of wastewater from almond industry using DSA-type anodes: direct connection 
to a PV generator," Separation and Purification Technology, vol. 123, pp. 15-22, 2014.

[5] M. Kobya, E. Gengec, and E. Demirbas, “Operating parameters and costs assessments of a real dyehouse wastewater effluent treated by a continuous electrocoagulation process," Chemical Engineering and Processing: Process Intensification, vol. 101, pp. 87-100, 2016.

[6] A. Amour, B. Merzouk, L. Jean-Pierre, and F. Lapicque, "Removal of reactive textile dye from aqueous solutions by electrocoagulation in a continuous cell," Desalination and Water Treatment, vol. 57, no. 48-49, pp. 22764-22773, 2015.

[7] B. K. Korbahti and K. M. Turan, "Evaluation of energy consumption in electrochemical oxidation of Acid Violet 7 textile dye using Pt/Ir electrodes," Journal of Turkish Chemical Society, Section A: Chemistry, vol. 3, no. 3, pp. 75-92, 2016.

[8] D. Valero, J. M. Ortiz, E. Expósito, V. Montiel, and A. Aldaz, "Electrocoagulation of a synthetic textile effluent powered by photovoltaic energy without batteries: direct connection behaviour," Solar Energy Materials and Solar Cells, vol. 92, no. 3, pp. 291-297, 2008.

[9] A. Masion, A. Vilgé-Ritter, J. Rose et al., "Coagulation-flocculation of natural organic matter with al salts: speciation and structure of the aggregates," Environmental Science \& Technology, vol. 34, no. 15, pp. 3242-3246, 2000.

[10] J. Gregory, "Laminar dispersion and the monitoring of flocculation processes," Journal of Colloid and Interface Science, vol. 118, pp. 397-409, 1987.

[11] A. Dalvand, E. Gholibegloo, M. R. Ganjali et al., "Comparison of Moringa stenopetala seed extract as a clean coagulant with Alum and Moringa stenopetala-Alum hybrid coagulant to remove direct dye from textile wastewater," Environmental Science and Pollution Research, vol. 23, no. 16, pp. 1639616405, 2016.

[12] A. Assadia, A. Soudavaria, and M. M. Fazlia, "Comparison of electrocoagulation and chemical coagulation processes in removing reactive red 196 from aqueous solution," Journal of Human Environment and Health Promotion, vol. 1, no. 3, pp. 172-182, 2016.

[13] C. Ricordel, A. Darchen, and D. Hadjiev, "Electrocoagulationelectroflotation as a surface water treatment for industrial uses," Separation and Purification Technology, vol. 74, no. 3, pp. 342-347, 2010.

[14] A. Othmani, A. Kesraoui, and M. Seffen, "The alternating and direct current effect on the elimination of cationic and anionic dye from aqueous solutions by electrocoagulation and coagulation flocculation," Euro-Mediterranean Journal for Environmental Integration, vol. 2, no. 1, 2017.

[15] S. L. Pérez, M. O. Rodriguez, S. Reyna et al., "Oil refinery wastewater treatment using coupled electrocoagulation and fixed film biological processes," Physics and Chemistry of the Earth, Parts $A / B / C$, vol. 91, pp. 53-60, 2016.

[16] H. Ahmad, W. K. Lafi, K. Abushgair, and J. M. Assbeihat, "Comparison of coagulation, electrocoagulation and biological techniques for the municipal wastewater treatment," International Journal of Applied Engineering Research, vol. 11, no. 22, pp. 11014-11024, 2016.

[17] C. Barrera-Díaz, G. Roa-Morales, L. Ávila-Córdoba, T. PavónSilva, and B. Bilyeu, "Electrochemical treatment applied to food-processing industrial wastewater," Industrial \& Engineering Chemistry Research, vol. 45, no. 1, pp. 34-38, 2006.
[18] C. Barrera-Díaz, L. A. Bernal-Martínez, R. Natividad, and J. M. Peralta-Hernández, "Synergy of electrochemical $/ \mathrm{O}_{3}$ process with aluminum electrodes in industrial wastewater treatment," Industrial and Engineering Chemistry Research, vol. 51, no. 27, pp. 9335-9342, 2012.

[19] ISES, "Transición hacia un futuro basado en las fuentes renovables de energía," Asociación Internacional de Energía Solar, 2003, https://mba.americaeconomia.com/sites/mba. americaeconomia.com/files/paper_ises_dieter_holm.pdf.

[20] S. M. Lucas, R. Mosteo, M. I. Maldonado, S. Malato, and J. A. Peres, "Solar photochemical treatment of winery wastewater in a CPC reactor," Journal of Agricultural and Food Chemistry, vol. 57, no. 23, pp. 11242-11248, 2009.

[21] A. M. S. Solano, C. K. Costa, D. Araujo et al., "Decontamination of real textile industrial effluent by strong oxidant species electrogenerated on diamond electrode: viability and disadvantages of this electrochemical technology," Applied Catalysis B: Environmental, vol. 130-131, pp. 112120, 2013.

[22] O. T. Can, M. Bayramoglu, and M. Kobya, "Decolorization of reactive dye solutions by electrocoagulation using aluminum electrodes," Industrial \& Engieneering Chemistry Research, vol. 42, no. 14, pp. 3391-3396, 2003.

[23] P. K. Holt, Electrocoagulation: Unravelling and Synthesising the Mechanisms behind a Water Treatment Process, [Ph.D. thesis], Chemical Engineering, University of Sydney, Australia, 2002.

[24] American Public Health Association, American Water Works Association, and Water Environment Federation, Standard Methods for the Examination of Water and Wastewater, L. S. Clesceri, A. E. Greenberg and A. D. Eaton, Eds., Washington, DC, USA, 1995, https://ses.library.usyd.edu.au/handle/2123/ 624.

[25] P. Aravind, V. Subramanyan, S. Ferro, and R. Gopalakrishnan, "Eco-friendly and facile integrated biological-cum-photo assisted electrooxidation process for degradation of textile wastewater," Water Research, vol. 93, pp. 230-241, 2016.

[26] T. Harif and A. Adin, "Characteristics of aggregates formed by electroflocculation of a colloidal suspension," Water Research, vol. 41, no. 13, pp. 2951-2961, 2007.

[27] A. S. Fajardo, R. F. Rodrigues, R. C. Martins, L. M. Castro, and R. M. Quinta-Ferreira, "Phenolic wastewaters treatment by electrocoagulation process using $\mathrm{Zn}$ anode," Chemical Engineering Journal, vol. 275, pp. 331-341, 2015.

[28] P. Cañizares, C. Jiménez, F. Martínez, C. Sáez, and M. A. Rodrigo, "Study of the electrocoagulation process using aluminum and iron electrodes," Industrial \& Engineering Chemistry Research, vol. 46, no. 19, pp. 6189-6195, 2007.

[29] E. Lacasa, P. Cañizares, and M. A. Rodrigo, "Production of coagulant reagents for electro-coagulation processes at low current densities," Desalination and Water Treatment, vol. 45, no. 1-3, pp. 256-262, 2012.

[30] Z. Gu, Z. Liao, M. Schulz, R. J. Davis, C. J. Baygents, and J. Farrell, "Estimating dosing rates and energy consumption for electrocoagulation using iron and aluminum electrodes," Industrial \& Engineering Chemistry Research, vol. 48, no. 6, pp. 3112-3117, 2009.

[31] H. Inan, A. Dimoglo, H. ŞimŞek, and M. Karpuzcu, "Olive oil mill wastewater treatment by means of electro-coagulation," Separation and Purification Technology, vol. 36, no. 1, pp. 23-31, 2004. 
[32] Ü. T. Ün, S. Uğur, A. S. Koparal, and Ü. B. ÖğÜtveren, "Electrocoagulation of olive mill wastewaters," Separation and Purification Technology, vol. 52, pp. 136-141, 2006.

[33] A. S. Fajardo, R. C. Martins, and R. M. Quinta-Ferreira, "Treatment of a synthetic phenolic mixture by electrocoagulation using $\mathrm{Al}, \mathrm{Cu}, \mathrm{Fe}, \mathrm{Pb}$, and $\mathrm{Zn}$ as anode materials," Industrial \& Engineering Chemistry Research, vol. 53, no. 47, pp. 18339-18345, 2014.

[34] M. Pourbaix, Atlas of Electrochemical Equilibria in Aqueous Solutions, Pergamon Press, Oxford, 1st edition, 1966.

[35] O. Nurgul and S. Y. Adife, "Factorial experimental design for Remazol Yellow dye sorption using apple pulp/apple pulp carbone-titanium dioxide co-sorbent," Journal of Cleaner Production, vol. 100, pp. 333-343, 2015.

[36] M. A. Sandoval, J. L. Nava, O. Coreno, G. Carreno, L. A. Arias, and D. Mendez, "Sulfate ions removal from an aqueous solution modeled on an abandoned mine by electrocoagulation process with recirculation," International Journal of Electrochemical Science, vol. 12, pp. 1318-1330, 2017.

[37] S. Liu, X. Ye, H. Kuang, Y. Chen, and H. Yongyou, "Simultaneous removal of $\mathrm{Ni}(\mathrm{II})$ and fluoride from a real flue gas desulfurization wastewater by electrocoagulation using $\mathrm{Fe} / \mathrm{C} / \mathrm{Al}$ electrode," Journal of Water Reuse and Desalination, vol. 7, no. 3, pp. 288-297, 2017.

[38] K. Wang Lawrence, H. Yung-Tse, and K. Shammas Nazih, Eds., "Advanced physicochemical treatment technologies," in Handbook of Environmental Engineering, vol. 5, p. 305, Humana Press, 2007.

[39] D. Valero, J. M. Ortiz, V. García, E. Expósito, V. Montiel, and A. Aldaz, "Electrocoagulation of wastewater from almond industry," Chemosphere, vol. 84, no. 9, pp. 1290-1295, 2011.

[40] D. Valero, V. García-García, E. Expósito, A. Aldaz, and V. Montiel, "Electrochemical treatment of wastewater from almond industry using DSA-type anodes: direct connection to a PV generator," Separation and Purification Technology, vol. 123, pp. 15-22, 2014.

[41] M. M. Quintero, S. T. Pavón, M. G. Roa, and R. Ruiz Meza, "Remoción de un colorante en medio acuoso utilizando un proceso electroquímico y energía eólica," in Tercer Congreso Internacional de Ciencias Ambientales. Sustentabilidad y Cambio Climático, Universidad Autónoma del Estado de México, Toluca, Estado de México, 2016.

[42] S. Lacey, Ed., Producing Solar Below 70 Cents a Watt, 2010, http://www.renewableenergyworld.com/rea/news/podcast/2010/ 09/producing-solar-at-70-cents-a-watt. 

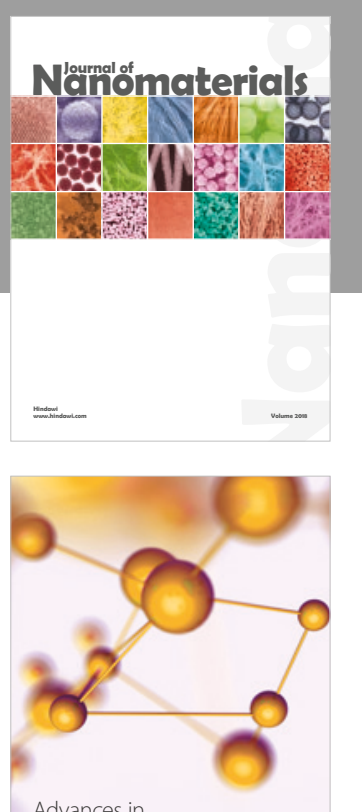

Physical Chemistry
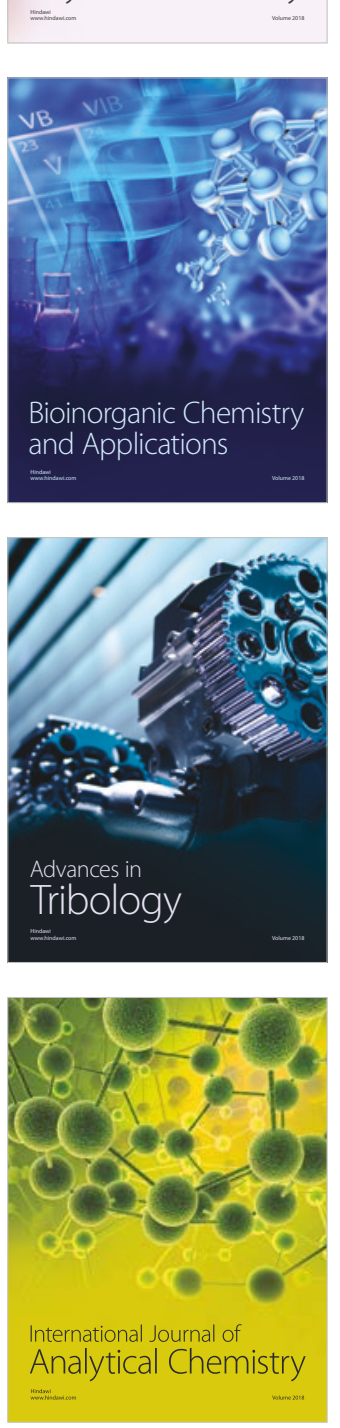

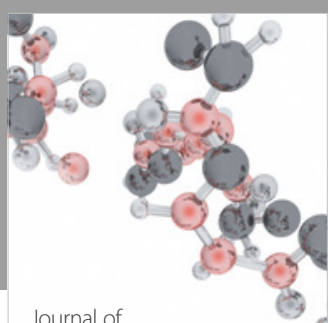

Analytical Methods

in Chemistry

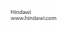

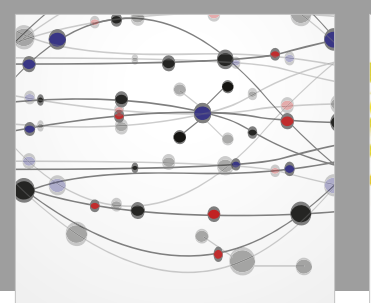

The Scientific World Journal

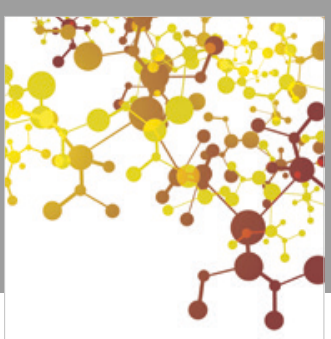

Journal of

Applied Chemistry
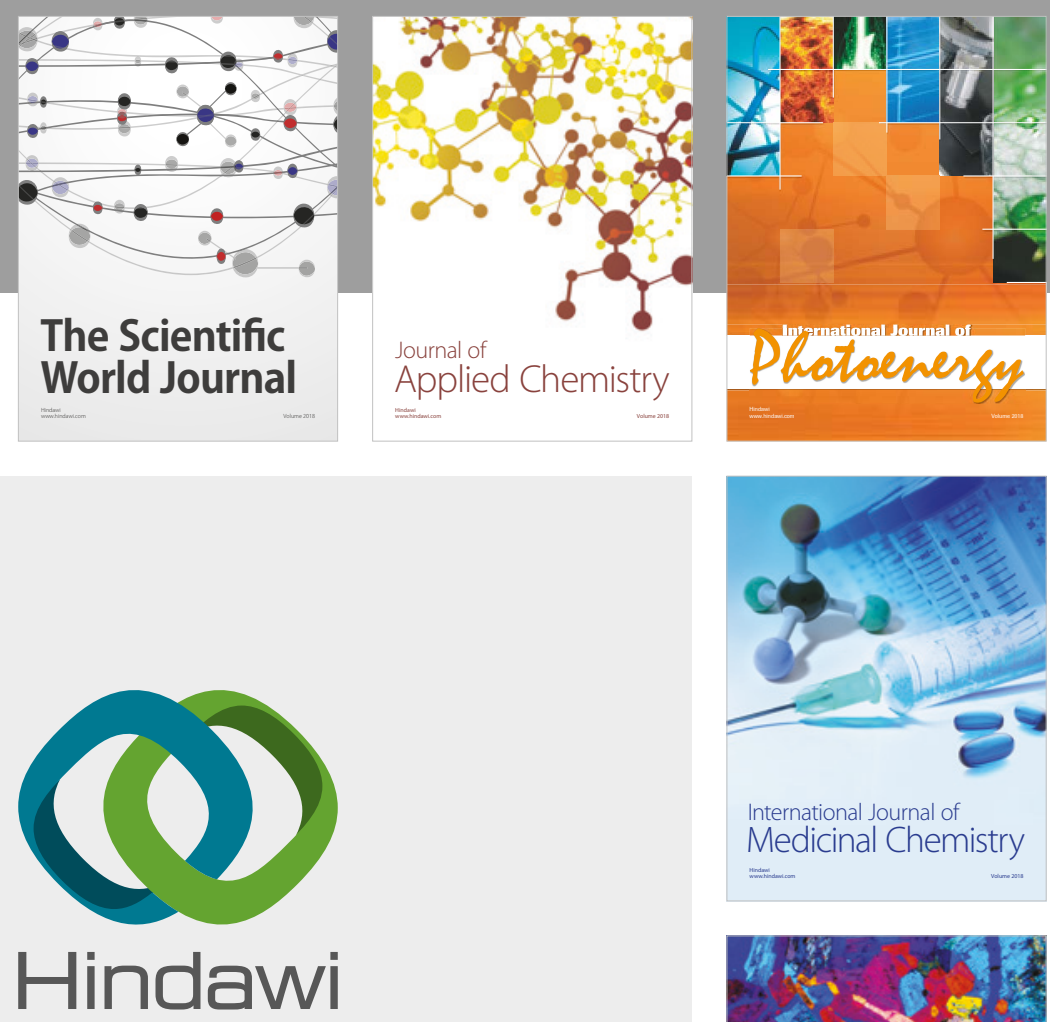

Submit your manuscripts at

www.hindawi.com
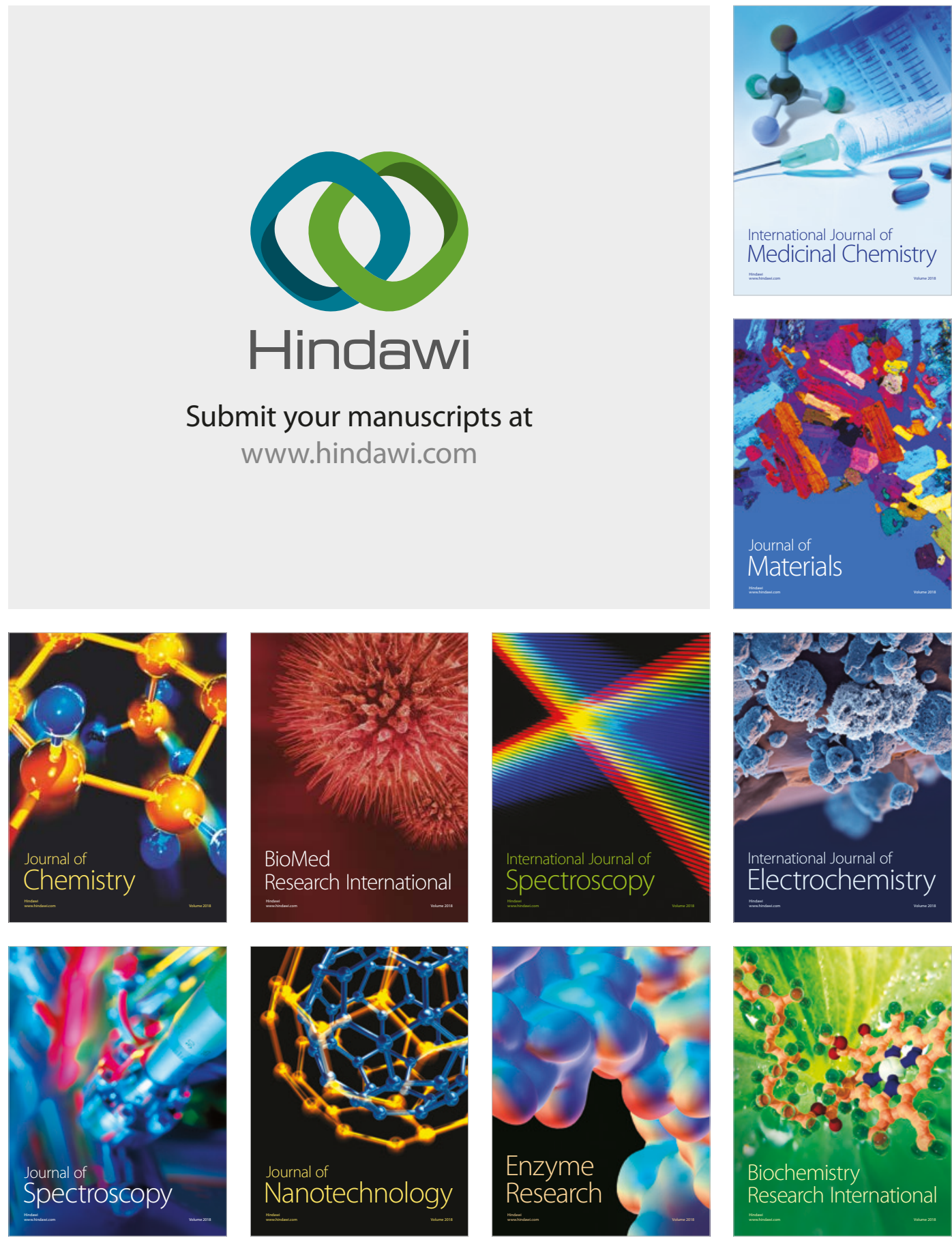
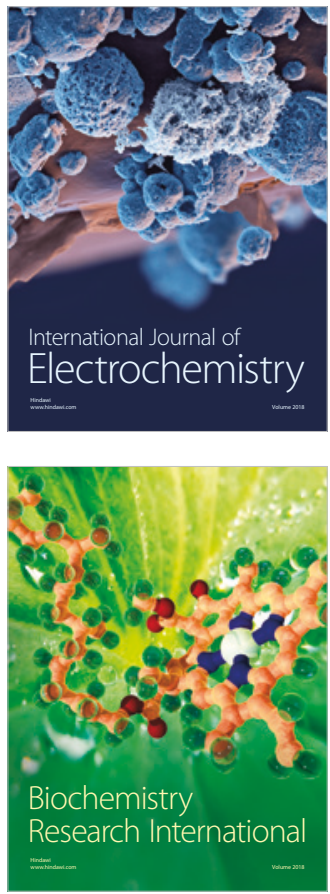